\title{
FIGURATIONS OF THE BODY IN THE SNAPSHOT OF DIGITAL PHOTOJOURNALISM: THE NON-POSE AND DISFIGURATION
}

\author{
Alene Lins, Madalena Oliveira \& Luís António Santos
}

\begin{abstract}
This article analyses the technological changes that have modified the snapshot in photojournalism. Formerly, snapshot was a result of the technique and expertise of the photographer. Today, due to a kind of "agility" of the cameras, it has become a possible practice for any photoreporter. Sequential photographs turn the portrayed subject's body into a pliant element of the editorial process. In figurations that privilege unfulfilled gestures and disfigurements, some images published by the press symbolically alter the social representation of the person portrayed. The study described within this paper also points to the use of an aesthetic of the grotesque, present in the expressions, gestures and posture of the subject photographed and to a discourse of the snapshot as a regime of power exerted by the press.
\end{abstract}

KeYwORDS

Snapshot in photojournalism; non-pose; social image; aesthetics of the grotesque

\begin{abstract}
Resumo
Este artigo analisa as alterações tecnológicas que modificaram o espontâneo do fotojornalismo. Antes, o espontâneo era resultado da técnica e perícia do fotógrafo. Atualmente, graças a uma espécie de "agilidade" das câmaras fotográficas, ele tornou-se uma prática possível a qualquer foto-repórter. As fotografias sequenciais tornam o corpo do sujeito retratado um elemento manipulável do processo editorial. Em figurações que privilegiam gestos não concretizados e desfigurações, algumas imagens publicadas na imprensa alteram simbolicamente a representação social do retratado. O estudo apresentado neste artigo também aponta para o uso de uma estética do grotesco presente nas expressões, nos gestos e postura do sujeito fotografado e para um discurso do espontâneo como um regime de poder exercido pela imprensa.
\end{abstract}

\section{Palavras-chave}

Espontâneo no fotojornalismo; não-pose; imagem social; estética do grotesco

\section{FOCUSING ON THE SNAPSHOT}

The single photo - the decisive moment or a moment of frozen time - as defended by Erich Salomon in the 1920 s and by Henri Cartier-Bresson in the 1950s, gave rise to the use of snapshots in photojournalism (Freund, 1983; Sousa, 2001). This is a tradition of factual genres, which does not accept and form of simulation or staging, and which portrays the subject almost always in action during an ongoing event. At the time when snapshots first began to be used, it was the photographer's responsibility to master a 
series of manual commands and use the sensitivity of his gaze to trigger the shutter at the precise instant to capture a frozen image that conveyed an entire moment (Freund 1983, Machado 1984). However, evolution in photographic technology, which began in the 1970 s and became more pronounced in the 2000s, now enables any photographer to shoot in burst mode. As a result, the current conditions underpinning the so-called technique of snapshot photography are more technological than artistic, wherein the social construction of the image of the portrayed subjects is shifted from the moment when the photos are initially taken, to the selection and editing stage.

The fractioned recording of each body movement of the portrayed subject has given rise to a phenomenon that is increasingly used in the editorial strategies of newspapers, magazines and websites: to choose body figurations that lie beyond what we culturally perceive as being normal. If "to photograph is to appropriate the thing photographed", as Susan Sontag (2004, p. 8) once stated, the photographed body becomes an object that may be manipulated in the editorial selection processes used in photojournalism. A photo editor, when choosing a pose, non-pose or a disfigurement of a portrayed person, transforms this figuration into an integral part of the news.

This article focuses on the technological changes that have enabled people's bodies to be photographed in burst mode. We consider that the growing use of snapshots in the form of non-poses, non-materialised gestures and disfiguration result from the new technical conditions available within the photographic medium. The approach developed in this paper is the result of a literature review, which seeks to interpret the aesthetics of this snapshot in its association with the grotesque style, viewed from the perspective of Bakhtin's concept: "exaggeration, hyperbolism, excessiveness are generally considered fundamental attributes of the grotesque style" (Bakhtin 1987, p. 265).

Through critical analysis of the reviewed literature, we apply the deductive method, in order to understand the historical processes associated to the emergence of the snapshot and demonstrate that it is no longer justified as a technique. The snapshot has, in fact, become a technological practice. Our theoretical path of enquiry, which associates the snapshot to the grotesque style, has been established in dialogue with Anthropology, Psychology, Sociology and Aesthetics, concerning figurations of the body as information - a basic principle of photojournalism.

\section{THE SNAPSHOT IN PHOTOJOURNALISM, FROM TECHNIQUE TO PRACTICE}

In the early years of documentary photography - far removed from the naturalization effect of the universe of images described by Anabela Gradim (2007, p. 190) - the pose was a necessity, for technical reasons. However, photojournalistic coverage of two wars helped to clarify the difference between photo-documentalism based on posed images, and a more realistic approach. The respective two wars, whose photographic coverage was subject to the same technological constraints, spawned divergent conceptual results. Photographic coverage of the Crimean War, commissioned in 1855 by the photographer Roger Fenton, resulted in 360 images. The photos include portraits of officers, 
landscape shots of the military camp, pictures of the soldiers in moments of rest, on horseback, holding their weapons, but always with very dignified poses'. Working for the British Crown, Fenton aimed to produce images that would provide encouragement for the soldiers' relatives. With an exposure time that ranged from 10 to 15 seconds per photo, he efficiently staged the photographs, since many seem to depict ongoing actions. The images were published and had a major impact on European society. Six years later, in 1861, Mathew Brady, Alexander Gardner, and Timothy O'Sullivan, while filming the American Civil War, produced the first work of realistic photo-documentalism, with starkly different results. They showed scenes with a line of soldiers' bodies, many of which were mutilated, destroyed houses, situations of horror and violence in the trenches that only war can cause. After comparing these two approaches, photo-documentalism and, subsequently, photojournalism, ultimately rejected the use of posed photographs to report factual situations (Freund, 1983; Sousa, 2002).

Jorge Pedro Sousa talks about the start of photojournalism based on realist genres, which later moved beyond the realm of truth towards a realm of credibility. The very creation of photo-documentalism strengthens the discussion of realism, before theoretical debates concerning point of view, perspective and other forms of manipulation, even prior to editing. But to some extent, photojournalism involves a dimension of social construction of reality, in keeping with the same dimension involved in journalism (Sousa, 1998). The Italian semiologist, Umberto Eco, in La Guerre du Faux, analysed the civilizational importance of the responsibility to produce a collection of historical images, which constitute part of the visual memory of our epoch. He cites a series of famous images, including that of the martyred Che Guevara, laid out on a stretcher in an army barracks, or the murdered militiaman photographed by Robert Capa, or the Vietnamese man photographed shortly before his execution. Umberto Eco says that "each of these images" - which summarize the vicissitudes of humanity after the invention of photography - "has become a myth and has condensed a series of discourses. It has overcome the unique circumstances that produced it ... and expresses concepts" (Eco, 1985, p. 212). The author continues, recognizing that each of these pictures "is unique, but at the same time refers back to other images that preceded it or followed it, by imitation" (Eco, 1985, pp. 212-213). Eco says that in modern civilization, in which we are accustomed to think in terms of images, such photos function as a reference, regardless of whether or not they constituted a simulation, i.e. were posed or staged. It's irrelevant whether or not they were taken by a professional photographer, who calculated the moment, light and composition. From the moment when a photograph with this imaginative force is published, and by virtue of the fact that it represents photojournalism, the Italian semiologist says that its "communicative march began: once again the political and the private have been crossed by the plots of the symbolic dimension, which, as always, proved that it is a producer of reality" (1985, p. 213).

Photographs began to be used in journalistic publications - in magazines and monthly periodicals - from 1885 onwards. In the opinion of Jorge Pedro Sousa, the

\footnotetext{
' Retrieved from http://www.allworldwars.com/Crimean-War-Photographs-by-Roger-Fenton-1855.html
} 
publications that favoured photography marked a conceptual change at this time, since the set of images ceased to hold secondary importance, solely used to illustrate the accompanying texts, and instead become an informational category in their own right: photojournalism, information provided via photography, a vehicle of observation, analysis and interpretation (Sousa, 2002).

The pose, as one figuration of photojournalism, was widely used, paradoxically even to give the impression of something that hadn't been staged, because the characters might not seem to have noticed the camera, but remained still to ensure a good image. Portrait photography was already one of the most widely published photographic genres (Freund, 1983). In its various genres, press photography disseminated portraits of both single characters and collective portraits, where new cultures could be seen:

the introduction of photography in the press is a phenomenon of fundamental importance. It changed the view of the working masses. Up until that point, the common man could only see the events around him, in his street, in his village. Photography opened a window on the world. The faces of the public characters, the events occurring across the country and abroad, became familiar. As one widens one vision, the world becomes smaller. (Freund, 1983, p. 96)

At first, because of technical impossibilities, involving large and heavy equipment, flashes that burst into flame and smelled of sulphur, photojournalism attracted professionals primarily by virtue of their physical characteristics, rather than their technicalsensorial skills. It was only in the 1920s, with the fast-paced cultural, social and scientific changes that were taking place in Germany, associated with the invention of smaller cameras, a new generation of photographers came onto the scene, whose concept of authorial work enabled technical and aesthetic development in the field of photojournalism. The photographers of this period, in stark contrast with their predecessors, had been educated how to behave, how to dress, and could speak various languages. It was this environment that spawned doktor Erich Salomon, a lawyer who spent five years working as a photo-reporter (1928-1933).

Salomon initially used a small, compact Ermanox camera, with a fast lens, which allowed him to shoot indoors without a flash. He then began shooting with an even lighter Leica camera, with interchangeable lenses and film rolls with 36 shots, which gave him greater autonomy. His work stood out from his colleagues, by virtue of this equipment, complemented by his extraordinary skill as a photographer. Salomon produced pictures of influential people in unusual situations, without them noting the presence of the camera. He thereby created a unique shooting style, mainly portraying influential people. The style adopted by Salomon became known as candid photography and engendered other genres, to the point of constituting a specific discourse of photojournalism - a snapshot which captures a spontaneous moment, an intrinsic relationship between interrupting the pose of the subject and highlighting the realism of the event, thereby reinforcing the character of a photograph that aims to convey the truth (Freund, 1983; Sousa, 2002). 
This was the beginning of modern photojournalism, in which the information conveyed is more important than the image's technical quality. Salomon's photographs were published in leading Western newspapers and he was, in fact, the first person to use the term "unique photo" in press photography (Freund 1983, p. 105).

Later, in 1952, the French photographer Henri Cartier-Bresson published the book Images a la Sauvette, published in English under the title The decisive moment, featuring images of moments when something important happens, thereby reinforcing the idea of the unique photo. Cartier-Bresson was one of the partners of the agency Magnum Photos, created in 1947, in a collaborative system involving many talented photographers, whose initial goal was to produce auteur photographs, in journalistic and documentalist missions around the world ${ }^{2}$. His book conceptualised the "decisive moment" as the capacity to record a unique moment, when the photographer manages to concentrate the entire meaning of a fact into a single image. The unique moment can thus be an action, a gesture, an expression of the photographed subject, and may also be a combination of elements in the background, which, without eclipsing the main motif, help us to understand the key issues at stake in the event (Sousa, 2002). Over the course of his professional career, Cartier-Bresson published his photos in prestigious journalistic outlets, held several exhibitions and won an extraordinary number of awards. He was, admittedly, one of the masters of the spontaneous snapshot ${ }^{3}$.

Salomon and Bresson, through the results of their photographs, their prestige and historical recognition as talented professionals, and by sustaining their practices on the photographic technique which they had mastered, reinforced the discourse of non-posed press photographs. Salomon and Bresson had complete control over the camera's mechanics and optics, the effects of light, complemented by the sensitivity of their gaze. For these reasons they constitute the two strongest contributions to the genres of spontaneous snapshots within photojournalism. But both demonstrated that mastering analogue technology required expertise.

The operator, i.e. the person who operates the camera, according to Barthes (1984), needed to coordinate many tasks during the era of completely manually controlled photographic equipment. The operator had to make calculations to quantify the amount of available light, and the speed / time that the film should be exposed to this light, observe the depth of field on the basis of the aperture used and the distance from the object, choose the best position and angle to frame the shot, select the composition, wait for the best moment on the camera's viewfinder, operate the focus ring, adjusting it as the subject moved, and finally press the shutter release button ${ }^{4}$. If it was necessary to produce a sequence of photos, the photographer using an analogue camera needed to manually advance the film before being able to take a new shot. It was impossible to take dozens

\footnotetext{
${ }^{2}$ Retrieved from https://www.magnumphotos.com/about\%2omagnum/overview/

${ }^{3}$ Retrieved from https://www.magnumphotos.com/photographer/henri-cartier-bresson/

${ }^{4}$ Empirical observations conducted by the researcher, who worked for 10 years as a photographer in the analogue period, first using a Nikon FM10 and Pentax K1000, with manual control, then s Canon EOS 50, with an electronic motor drive (1992 to 2002).
} 
of photos per second. A highly skilled photographer might be able to achieve two or three fps (photos per second). In the press context, the photo-reporter also needed to have a power of synthesis of the event, to the point of producing few images that would generate meaning for the event.

Bresson and Salomon demonstrated that journalistic photographs are artefacts of personal, social, cultural, ideological and technological genesis, since each photo-reporter has a unique capacity, perception, aesthetic sense, professionalism, ethical standards, together with skills in handling the technology (Sousa, 1998). Framing the composition involves a process of choices, in terms of lenses, framing or point of view, and everything interferes with the outcome. In addition to this stage of production, publication of press photographs also involves another professional - the photo editor - who chooses which image will be published and its prominence in the publication as a whole.

The discourse of the snapshot underpinned the genres of factual photography, of coverage in loco, an editorial space in which the pose and the staged image were reviled. Genres such as spot news, general news, features, sport, among others, all embody characteristics of the snapshot image (photos of the precise moment in time when the facts happened), and are grounded in the spontaneous reaction (i.e. without any simulation, or staging). A personality, whether a politician, artist, or athlete, in factual photography, is almost always portrayed via a figuration that expresses an action in progress, without evident elaboration (Sousa, 1998; 2002).

While the discourse of the spontaneous snapshot image was progressively strengthened, technological changes related to press photography began to occur, although relatively slowly. In 1958, six years after publication of Henri Cartier-Bresson's book, The decisive moment, Leica launched an experimental camera with an electric motor - the MP2 - whose first batch only included 12 units, followed by a further 15 units in 1959. These were the first cameras released into the market which didn't require the film to be advanced by hand. Instead the new cameras advanced the film automatically, after each shot. These cameras were never manufactured on a large scales. They were so revolutionary that they have great historical value and therefore, also high market value for collectors. In 2010, one of these units was sold in an auction for $€ 402.000$ (Máquina fotográfica Leica vendida por valor recorde, 2010).

In the 1960s, other brands also launched motors that could advance and rewind the film. They were external motors that were coupled to the camera. Cameras with an integrated motor drive were key innovations in the 1970s. One of the most important was the Nikon F line, which could shoot at seven $\mathrm{fps}^{6}$. The motor drive speeded up the process, saving the photographer's time to make adjustments. During this period there began to be a significant change in snapshot photography, since it became possible to take 36 photos of a subject, in burst mode, in a few seconds. Professional photographers used to use film rolls with more frames, in an artisanal system, although at a very limited

\footnotetext{
${ }^{5}$ This insformation can be confirmed in Leica's website, available at LeicaPhilia.com

${ }^{6}$ Retrieved from http://imaging.nikon.com/history/chronicle/rhnco4f2-e/index.htm
} 
scale. There was also a process to speed up the replacement of each roll of film, in which the film was fully rewound thereby ensuring that the film was protected from the light. In addition, there was manual insertion of another roll of film into the camera, which took a few minutes. The professional photographer, knowing this, used film with some care, so as not to run the risk of running out of frames at an important moment of coverage?.

The 1990 s brought changes to the means of production, storage and dissemination of photographs, and this reality also altered the techniques of snapshot photography. In 1992, the Silicon Valley-based company, SanDisc, began research, in a consortium with Canon, Kodak and other photographic equipment manufacturers and in 1994 launched the first compact flash card. In 1997, the digital technology of sensors and memory cards became popular, with SanDisc producing 1 million cards that year ${ }^{8}$. As a result, by the early 2000 , digital cameras were perfected at lower and more affordable costs. According to Sílvia Pinto and Moisés de Lemos Martins, for this reason "in the contemporary era, photographs have become the visual experience, par excellence" (2017, p. 262).

A compact flash card makes it possible to take 100, 200 or more high-quality photos of a single event, for viewing and print purposes. As a result, the final barrier of manual processes was overcome. Digital cameras also enable continuous records of the shutter speed, since they have auto focus and automatic aperture settings. A photographer merely needs to continually accompany a person who is speaking and gesturing, and several photographs will be taken in a sequence. In view of the above, it is obvious that taking a snapshot no longer depends on the photographer's skill. But it nonetheless remains a discourse used by photojournalism, especially when a subject has his photo published, whose body figuration has meanings that lie beyond the field of normality of what we culturally associate with the social image of the portrait image.

\section{THE UNFULFILLED GESTURE, THE NON-POSE AND DISFIGUREMENT}

The snapshot is a form of photography in which shots are taken without any prior warning, and thereby arbitrarily freezes a moment in time. The snapshot thereby generates a figuration of the body for which the photographed person doesn't seems to have been previously prepared, where, apparently, there was no staging. There was no specific attitude of the subject directly associated to his or her figuration, prior to taking the photograph. The snapshot is a frozen image of a natural gesture, of a spontaneous expression. A snapshot is always based on the idea of a non-pose, a form of communication that is equally efficient as, or more efficient than, the posed image, when one thinks about decoding the message, in terms of the cultural association linked to the posed image. After all, if it isn't a posed image, if it's more natural, if there was no staging, one enters the mythical domain of reality - the photographic symbolic image. In the absence of a posed image we presume that the subject can be seen without a mask.

\footnotetext{
7 The first author acted as freelancer photojournalist between 1992 a 2002, covering events for some small media companies. Observations are mentioned from that period.

${ }^{8}$ Retrieved from https://www.sandisk.com/about/company/history
} 
In photo journalistic coverage of interviews it is very common to see a subject in a situation of a non-pose, because this is a constant result when a person is photographed while speaking and gesticulating. He or she is unable to control his or her gestures or expressions, since speech requires the use of face muscles and the lines of expression of the face accompany the spoken words. At very high speeds and in burst mode, the shutter will register every expression and gesture, absence and presence, that not even the human eye can perceive in detail, thus contributing to a kind of "optical virtualization" - an expression that Maria Teresa Cruz borrows from Friedrich Kittler in a passage from an article in which he refers to modern technical images (Cruz, 2007, p. 30).

Even in the case of analogue photography, the camera made it possible to see what the eye couldn't see, such as the four legs of a horse "suspended" in the air, in a synchronous moment, which Eadweard Muybridge's experiments revealed in 1887 (Machado, 1984, p. 50). Muybridge used 12 cameras, with the shutter releases operating sequentially, using the chronophotography technique (Fabris, 2004). He left behind a collection of over 20,000 images, including his studies of horses and male and female nudes, only capturing bodies in motion. His works, showing that which the eye can't see, relating time and movement, inspired studies by Rodin and Degas, among other artists, and gave rise to the term "snapshot" in photography, according to Fabris (2004). Several years later, chronophotography enabled Walter Benjamim to theorize about the optical unconscious and how to see, through photography, what we can't perceive with the naked eye, allowing us to make new discoveries, giving us a new notion of the world and entering into fields of the imaginary.

We perceive, in general, the movement of a walking man, even in broad strokes, but notice nothing of his attitude during the exact split second in which he takes a step. The photograph succeeds in showing this attitude through its auxiliary resources: slow motion, magnification. Only the photograph reveals this optical unconscious, just as only psychoanalysis reveals the irrational one. (Benjamin, 1987, p. 94)

Today there are cameras that can take images at 10, 20, 25 thousand fps $\mathrm{fps}^{9}$, which frame by frame can reveal the flight of a hummingbird or the spreading of a drop of rain when it falls to the ground. But it is sufficient to watch a sequence of images recorded at $60 \mathrm{fps}$ for our eye to perceive several movements that were imperceptible without the camera. As a result, the optical unconscious is increasingly being revealed.

In photojournalism, when personalities are accompanied by several cameras, operated by experienced photographers, during a speech, the sequential shots will present several images of unfulfilled gestures. Barthes considered that these unfulfilled gestures recorded in the photograph represent something singular. He wrote: "what founds the nature of Photography is the pose" (Barthes, 1984, p. 117). For Barthes, the physical duration of a pose is irrelevant, since the pose isn't an attitude of the target, it isn't that the

${ }_{9}$ Retrieved from https://www.phantomhighspeed.com/Products/Ultrahigh-Speed-Cameras 
subject stops and places himself in a certain position, but instead the fact that he has been photographed, his image is paralyzed in time, there is freezing of the photographed subject, regardless of whether or not it was intentional. For the semiologist, the entire photographed subject is assuming a pose, because the photograph captures a movement and freezes it. Even if in fact the subject hasn't held such a position over time, or attempted to construe any meaning with the position, his photograph, in that position, will nonetheless generate meaning: a pose is implicitly produced whenever we take a photograph.

An example of an unfulfilled gesture, a result of the optical unconscious, was published in 1961, and affected the political life of the President of Brazil at that time, Jânio Quadros. After a stampede followed by a tumult, he turned to see what was happening behind him, and was photographed with an unusual body position: his legs were strangely twisted, in the image they appear to be moving in opposite directions (Figure 1). The photo was published in the Jornal do Brasil newspaper with the provocative title, "Which way forward?" The image won the Esso prize in the Photography category in $1962^{10}$. According to the historian Ana Maria Mauad (2008), Jânio was forever associated with this figuration, enmeshed in his own legs, in an imbalance that suggests an imminent fall. For the author, the image demonstrated a physical ambiguity that also marked Jânio's political life, and epitomised a unique moment in the country's history. Jânio Quadros resigned a few months later. In an interview with Mauad, Erno Schneider, who took the photograph, said that it was a unique photograph, a flagrant image (Mauad, 2008).

The photograph of Jânio Quadros portrays a moment in which a human being can't stand up for a long period of time, because it is an involuntary movement, a pure reflex that happens in a fraction of a second. As an image, that by nature has multiple meanings, it is certain that a photograph inspires countless interpretations, but the figurations of the body and face in Western culture, regardless of the fact to which they are associated, have their own intrinsic meanings. The meanings conveyed by the body, in certain news items, suggest values that are very different from the news value of the fact itself, and the news associated with the image of Janio is one example. This was a meeting between the President of Brazil and the President of Argentina, Arturo Frondizi. The associated news story wasn't the fact that Jânio was scared by the tumult caused by the stampede, because this was only subsequently revealed by the photographer when he spoke to the historian. But the image of Jânio, in that abnormal situation, was transformed into a photographic fact, and it was still the figuration of his body that was immortalized in the political history of this former President. The automatic mechanism that captured the optical unconscious of a moving body was responsible for the photograph. This image, however, was perceived by the Brazilian population as his pose - slanted - in the sense defended by Barthes.

\footnotetext{
${ }^{10}$ Retrieved from http://www.premioexxonmobil.com.br/site/premio_principal/index.aspx?year=1962
} 


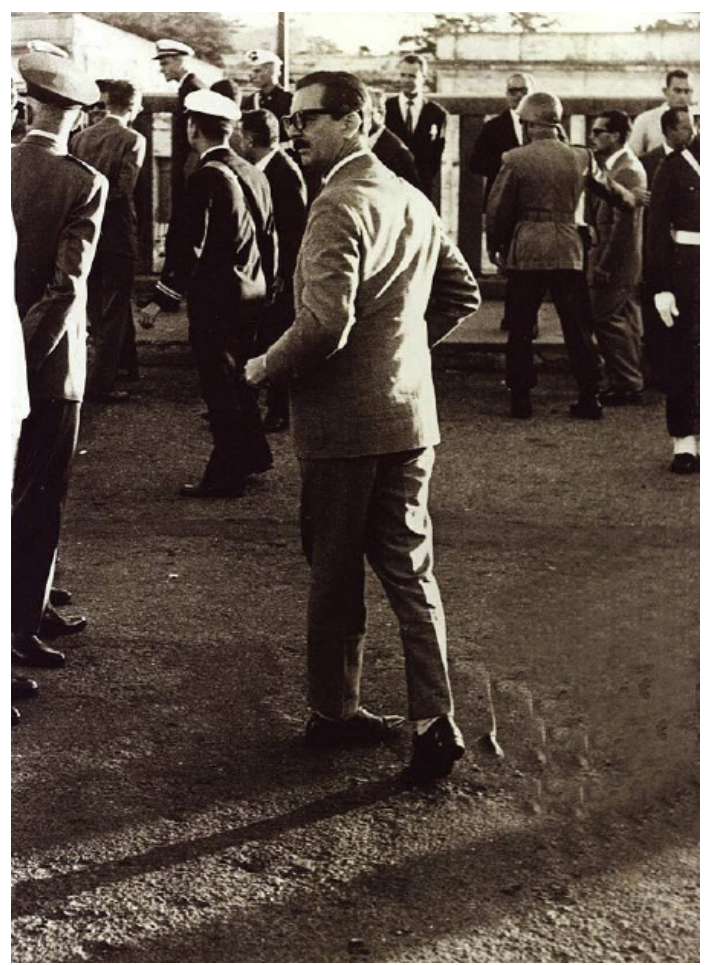

Figura 1: Which is the way? (in the photo, Jânio Quadros), Erno Schneider, 1961

Giddens contextualizes a set of research studies with different populations and their facial expressions, postures and gestures, and states that "as occurs with facial expressions, body posture and gestures are constantly used to complement verbal expressions and also convey meaning without anything being said" (Giddens, 2008, p. 85). Thus, we can conclude that a non-pose is also easily recognizable. As an image, it transmits different meanings even though there no words are said to express such meanings. Twisted legs, inelegant postures are inevitably associated to the idea of imbalance. If from the perspective of the experience of our own bodies we relate to the experience of someone else's body, we know that if someone's legs are twisted they won't be able to stand up for long. As a myth-image of photojournalism, after its publication in the Jornal do Brasil newspaper, this photograph of Jânio began its communicative march (Eco, 1985 , p. 212), since this figuration left a permanent mark on the history of the politician.

Another example of a controversial photograph, in which an unfulfilled gesture became a fact, involved US President Donald Trump and Canadian Prime Minister Justin Trudeau (Figure 2). Soon after Trump's inauguration, on February 13, 2017, their first official meeting took place. In one of the photographs, Trudeau seemed to hesitate before shaking Trump's hand. The news of the first official meeting between the two chiefs of nations was reduced by some tabloids to the meaning of the Canadian Prime Minister's reticent expression. The image was relentlessly recirculated, and became a meme". Repercussion of this scene in social networks became a news item in mass circulation

\footnotetext{
"Meme, from Greek: imitation; a term used in biology to categorise replication; a term used when there is excessive collective and parody-based recirculation of (fixed or moving) images and texts, by users of social networks via the internet and via smartphones (Horta, 2015).
} 
magazines such as Visão in Portugal and Veja in Brazil and also in television news. But it is possible to see in the video available in the site of The Guardian (2017, $14^{\text {th }}$ February) that Trudeau hadn't actually seen Trump's extended hand. He was looking at the photographers, while the US President held out his hand for a few seconds. Trudeau made a facial expression that seemed to express doubt, but it was actually directed at the photographers, as if he wondered whether they were ready to take the official photograph. This asymmetry in the movements of the two politicians generated a fake news item, a type of news that today is acknowledged as something that is composed and manipulated in order to resemble credible journalism and thereby attracts the highest public attention (Hunt, 2016). To a large extent, fake news items are largely fuelled by misinterpreted images. As Tito Cardoso e Cunha points out, political action today exists "essentially via the word, by discourse" (2009, p. 19), unfulfilled gestures and figurations generated by them and captured by a camera have an increasing impact on the perception of politicians' performances.

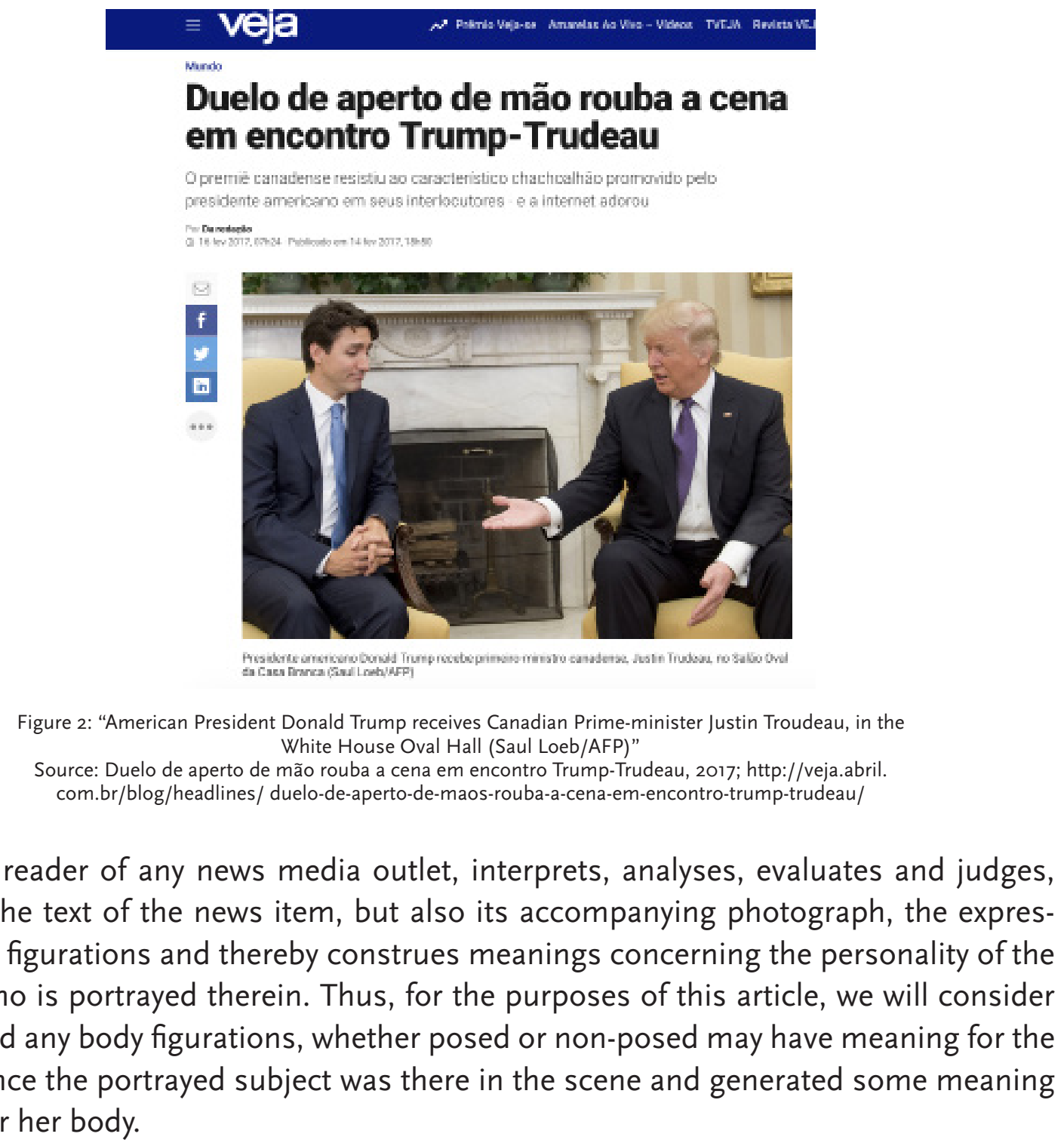


It is important to differentiate the non-pose into two categories: the standard nonpose and disfigurement. Shots taken without any warning constitute the antithesis of the posed image. Whereas the pose may be associated to power and status, due to the weight of cultural meaning associated to painting and photography catalogues, rooted in the habit of portraying powerful figures from the aristocracy and bourgeoisie (Barrocas, 2014), the non-pose, on the contrary, can undermine the social image of the person in question.

Arlindo Machado concludes that "nobody likes to be surprised by a snapshot, because the image it reveals to us always betrays the idea that we have about ourselves and that we want to pass on to others" (Machado, 1984, p. 51). A direct descendant of the aristocratic pictorial tradition, which is also an ideological remnant, the posed image isn't always "compatible with the democratic facilities of the photographic camera: instead it imposes a certain sublimation of the motif and a kind of 'natural selection' of the referents" (Machado, 1984, p. 58). Snapshots offer no guarantee that we will look good in the picture and this also makes us uneasy. This can be observed when we are in a group and one person decides to take a photo to record the moment. People inevitably adjust their posture, tidy their hair, straighten their clothes, change their expressions, and smile at the camera, because the snapshot is a record of the moment, but isn't necessarily a non-pose. A snapshot isn't always a spontaneous image. Barthes notes that whenever we feel we are looking at a lens, everything changes. "I constitute myself in the process of 'posing,' I instantaneously make another body for myself, I transform myself in advance into an image" (Barthes, 1984, p. 22).

The discomfort of striking a pose is considerable, but far worse is the mental discomfort of anticipating a distorted image, that differs from the public image that we want to convey to others and immortalize. There is a psychological and anthropological relationship between our body and the body image that we want to disseminate to others. In 1935, the Austrian psychiatrist, Paul Ferdinand Schilder, published the book The image and appearance of the human body, in which he presented the concept of the body-image. For Schilder, "the image of the human body means the picture of our own body which we form in our mind, that is to say the way in which the body appears to ourselves" (Schilder, 1999, p. 11). The body-image is intra and inter-personally related with the individual's emotions and feelings - with himself, with others and with his environment, with the use of garments and objects of adornment. Schilder suggests that the experience of our own body image and the experience of the bodies of others are closely intertwined.

According to Machado (1984), when we face a camera there is no reality that remains intact, because everything changes, arranges itself and competes for the ideal order of the monument (image). There are even those who, blessed by nature, can always be photographed in an interesting manner. This so-called quality of being photogenic, has no plausible explanation, because there are certain individuals who have little facial symmetry, but always look good in photographs. The world has witnessed the birth of a new profession - the photographic model - in which trained people are able to move around spaces with such elegance that "at any moment, or at any angle that the camera 
captures them, they always provide an idealised and classical image, but never the elastic and disdainful posture of someone who is surprised by a sudden snapshot" (Machado 1984, p. 52). But not everyone is photogenic. And many people are exposed to a camera for a considerable amount of time, such as personalities at public events where there is photo-journalistic coverage. How can someone control their face and body for so long?

The sudden snapshots taken by photo-reporters often also reveal deformed bodies and faces. These photos are sometimes chosen by a newspaper editor and published. A frozen image of a deformed body or face, regardless of the associated news value, when it is used to illustrate a fact, will inevitably generate other meanings.

Describing the ways that we understand the functions of the image, the French theorist Jacques Aumont spoke in an epistemic, very specific manner about how we establish a relationship between a person and the world, whose residual value, a value of an identical copy, extends the informational or referential function (Aumont, 1998, p. 80). Images serve to see the world and interpret it. In Aumont's opinion, there is still an aesthetic way to perceive the functions of the image, "by providing its viewer with specific sensations (aisthésis)" (Aumont, 1998, p. 80). The image, with its specific characteristics, with its plastic instruments, is a communication medium that solicits aesthetic enjoyment, since it stimulates a type of expectation in the spectator that is specific and different from the expectation that is stimulated by a verbal message. The researcher Martine Joly, in her book Introdução à análise da imagem (Introduction to Image Analysis), devotes a topic to the association between the image's referential function and aesthetic function, based on Aumont's ideas and articulating the two modes, in what she considers to be an intercession image (Joly, 1994, p. 62).

The non-standard body-image is an example of an intercession image. Disfigured, it carries with it all the meanings of the photograph that aims to express a newsworthy fact, but also embodies the metaphor of the mask that the press places on the people that it portrays, with its own specific aesthetic.

\section{FROM DISFIGUREMENT TO THE GROTESQUE}

Phenomenology considers that the aesthetic corresponds to a complex relationship between perception and experience. The spectator, when viewing a disfigured image, has an experience transmitted by the image, wherein his gaze receives a set of meanings that will draw from that experience. There are cultural values in the image of the disfigured that partake from the aesthetic fruition it provides. Wide-open eyes, a misshapen nose, an open mouth. In fact, the mouth - the part of the body that bites, the only violent structure in the face - when seen wide open is a sign of lack of control, and the other parts of the body, in an abnormal position, counter our notion of proportion and harmony. When distorted, human expression loses its balance, normality, and enters the aesthetic field of the grotesque. Helmut Jacobs (2014), analysing part of the work of the painter Francisco de La Goya, remarks that everything that is strange, deformed, ridiculous, irregular and abnormal, implies the grotesque. 
Mikhail Bakhtin says that the grotesque body goes beyond the body itself, displaces it into a non-corporal world. The grotesque face, like the body, is in motion, it is neither prepared, nor complete. Bakhtin considers that the mouth is the centre of the grotesque face, as "an open and devouring bodily abyss" (Bakhtin, 1987, p. 277).

It is true that the grotesque style has formed part of the human imagination since time immemorial and has been efficiently immortalized in painting: Caravaggio and his devouring faces; Goya and his deformed figures; Munch and the scream; Bosch with his obscure, caricatured and dantesque characters ... Albertino Gonçalves (2002) considers that the grotesque body is the antithesis of the classic canon.

In the paintings of the renaissance and classicism, bodies appear as individualities that are carefully detached from their surrounding social and natural background. Either inactive, or pursuing noble deeds, they become captive within the two-dimensional smoothness of the canvas - in an impassive pose, viewed at a fixed angle (...). the characters are harmoniously reified in compositions bathed by an aesthetics of timelessness. (Gonçalves, 2002, pp. 126-127)

By contrast, the author considers that in paintings of the grotesque, the figures appear without any polishing or censorship, with mundane elements, revealing the lower parts of the body, and expressive and animated faces that seem to want to leap out from the canvas.

Although Bakhtin criticizes the German researcher Heinrich Schneegans - the first person to attempt to construct a theory of the grotesque in 1894 - because he says that he ignored important and ambiguous questions, he nonetheless notes that Schneegans considers that the essential property of the grotesque is a caricature of a negative phenomenon, close to monstrosity, but whose ultimate purpose is satire (Bakhtin, 1987, p. 272). In images of the grotesque, the body stands at the centre, lowering its movement and the artistic modality is one of laughter. Everything in the grotesque is risible, includes a ridiculous dimension. "Laughter renders everything relative, arbitrary, transient, ephemeral, petty, in short, vulnerable" (Gonçalves, 2002, p. 128). The laughter provoked by the grotesque, is almost always a laughter of mockery, of derision. We laugh at the physical, the ridiculous, the abnormal, but that which causes this laughter, is extrapolated. We actually laugh about the character, the psychological, the spiritual dimensions revealed by the unconstrained body. A correlation between the physical realm, the personality and the spiritual dimension, as explained by Vladimir Propp (Propp, 1992).

For this reason, we believe that editorial processes associated to selecting disfigured images also involve criteria of the moral authority of the person portrayed in the image. In the same manner that the pose incorporates a social value, pre-established in the symbolic-cultural order, this is also true of the grotesque. The pose is configured in the search for an identity of the subject, in the construction of an image that represents the subject, in a rounded and finished state of perfection. By contrast, the grotesque shows that which shouldn't be revealed - recesses, abysses, orifices, an unfinished body, exaggerated gestures. 
The grotesque exerts tremendous fascination for the spectator, since it has a subversive function and causes anguish due to the deformation of the body. It is also associated with the legitimacy of a snapshot published in international media outlets. The "noema This-was" (Barthes, 1984, p. 115) is the certainty that the portrayed body appeared in that manner in front of a lens, transferring to the portrayed person the responsibility for positioning his body in a disfigured manner, and ignoring the choice made in the editorial process, to justify publication of the image. This complexity is even greater if we consider the subjective universes of the sociology of power, associated with the images of persons from the political sphere. In this manner, photographs of the subject, revealing twisted expressions, create a grotesque, voracious and corrosive discourse that subverts the value system, which according to Martins is: "averse to perfection, beauty and sublime, wherein nothing can be salvaged" (Martins, 2011, p. 188).

On the other hand, Gonçalves (2002) suggests that the grotesque power pulsates within the veins of the social universe, in order to purge and renew society. In his opinion, the extraordinary grotesque image cohabits and interacts in daily life as a manifestation that stands contrary to established power. Absoluteness and perfection are sterile and dangerous illusions, which must be relativized and tempered, and Gonçalves considers that the discourse of the grotesque assumes this function, by showing unfinished, mutilated, distorted and incomplete subjects. In this manner the dominant categories fall apart. Official speeches lose strength and meaning in the turmoil of the grotesque. Gonçalves considers that in the grotesque universe, "the main protagonists tend to be hyperbolic and exorbitant collective subjects" (Gonçalves, 2002, p. 119). For this reason, the use of the grotesque snapshot in photojournalism is a phenomenon that seems to affect politicians all over the world.

Gonçalves uses Bakhtin's ambivalence to talk about the renewing force of the grotesque, since the process of degrading, connected to the lower parts of the body, is also a means of connecting with that which is most human, causing ruptures and rebirth, redeeming via pollution. Gonçalves (2002) notes that the grotesque is increasingly present in society - whether in terms of photography, plastic surgery, or the cyborg-style effects of cutting-edge technology used in amputees, in regenerative medicine. In his opinion, the grotesque is highly present in modern society and seems to be a growing phenomenon, if one looks at the cinema, advertising, video games, and reality TV programmes. No doubt we can add photojournalism to this list.

The grotesque photographic images published in leading national and international media outlets, involve an intention to create caricatures and transform a news-based instrument into a weapon of laughter that ridicules the person photographed. Is photojournalism a form of disowning or humanizing powerful people who stand above ordinary mortals? Does the photograph of the grotesque - that transforms the subject into a caricature of itself, which causes distortion of forms and, therefore, of the established order - a means of withdrawing power, by undermining the authority of politicians and influential people? Does being under the watchful eye of the camera mean that the subject is always susceptible to grotesque transformation? 
According to Anthony Giddens (2008, p. 424), the study of power is of utmost importance for Sociology, since power exists in all social relations. He conceives power as the capacity held by individuals or groups to assert their own interests, even when others oppose them. The press, by choosing a photograph with a certain pose or with a non-pose, to a certain extent is giving or removing power to/from the photographed subject, by virtue of the figuration of body in the respective image. The press by using the snapshot as a discourse, as a technique, wherein any photo-reporter with suitable cameras (technology-power) can take snapshots, imposes a situation of transfiguration on the portrayed subject. The editor's process of choice, when he chooses the grotesque image from a range of photographs, exerts power over the body of the portrayed person and his social image.

\section{FinAL CONSIDERATIONS}

Any and all media images result from a discursive process, that derives from the choices made by photographers, editors, designers who, when publishing a photograph in a newspaper, magazine or website, choose specific elements of composition, titles, accompanying captions, tonalities, contrasts, cuts. In the case of a photographed person, they can also choose the person's body figuration, expression and gesture.

Digital processes - with memory cards and automatic cameras - have facilitated and strengthened the discourse of the snapshot. Photojournalism has abandoned the "decisive instant", and now relies on technical resource that produce a sequence of snapshots, in burst mode, in which the body of the portrayed subject can be used against him. Many people are portrayed in this manner. All media outlets post photos in this style. It is a modus operandi. An established symbolic system (Bourdieu, 1989, p. 16).

Pierre Bourdieu wrote how important it is to discover the places where power is less visible, although this doesn't mean that it is minor. There are types of power that seem to neither exist nor place pressure on other things. The discourse of the snapshot harbours this kind of power. It is an ignored power. A symbolic power, relatively unrecognized, almost invisible, "which can only be exercised with the complicity of those who do not want to know that they are subject to it or even that they exercise it" (Bourdieu, 1989, p. 8).

Photojournalism pretends it has no control over the body of another person. But those who work with a professional camera while covering news events know how much the subject's image lie under their control. The snapshot, as used today, is not a reality but a simulation, a discourse that remains real, since it exists in theory, supported by a tradition. However, most snapshots are now taken without the skill and talent of a photographer, and are primarily made viable by modern technology. Before all the possibilities of spreading social images of other people, generated via cameras operating in burst mode, the editor often chooses an unfulfilled gesture. In reality, the subject didn't stop his speech half-way through, make a distorted face and then continue.

Vilém Flusser compares a photographer to a hunter, operating a weapon (the camera) with a trigger (the shutter release), whose intention is to capture an image. This 
image is categorized into cultural regions at the time of shooting. The photographer doesn't film processes, as in the cinema, where there is movement and continuity. Instead the photographer freezes processes because he chooses a single moment, he removes the scene from its context:

in order to take a photograph, the photographer, first and foremost, needs to conceive his aesthetic, political, etc., intention, because he needs to know what he is doing when manipulating the camera's outputs. The manipulation of the apparatus is a technical gesture, i.e. a gesture that articulates concepts, prior to being able to translate it into images. In photography there can be no ingenuity. (...) Any aesthetic, political or epistemological intention must, necessarily, go through the sieve of conceptualization, before producing an image. The device has been programmed for this. Photographs are images of concepts, they are concepts translated into scenes. (Flusser, 1998, p. 52)

Thus, when a photo-reporter freezes an image, whether posed, or a spontaneous moment, a non-pose or a disfigurement, he knows perfectly well why he does it and the scene that will be frozen doesn't depend on the photographed subject. But due to the dimension of the social construction of reality, in keeping with the same dimension that receives journalism, a photograph published in the press can generate other subjectivities.

Thus, perpetuating a practice, under the discourse of taking spontaneous snapshots that is no longer justified as a technique, perhaps valorise grotesque images, naturalizing them as discourses of the photographed subject rather than editorial discursive processes. The social image of a portrayed, caricatured subject, associated with the grotesque, gains a new meaning in the social imaginary.

Translated by Martin Dale (Formigueiro Lda)

\section{BibLIOGRAPHIC REFERENCES}

Aumont, J. (1998). A imagem. Campinas, São Paulo: Papirus.

Bakhtin, M. (1987). A cultura popular na idade média e no renascimento: o contexto de François Rabelais. São Paulo: Hucitec.

Barrocas, A. (2014). Sais de sangue - o corpo fotografado: teoria e prática da fotografia em Portugal. Phd Thesis, Universidade de Lisboa, Lisbon, Portugal. Retrieved from http://repositorio.ul.pt/handle/10451/15632

Barthes, R. (1984). A câmara clara. Rio de Janeiro: Nova Fronteira.

Benjamin, W. (1987). Magia e técnica, arte e política: ensaios sobre literatura e história da cultura. São Paulo: Brasiliense.

Bourdieu, P. (1989). O poder simbólico. Lisbon: Difel. 
Cruz, M. T. (2007). Espaço, média e experiência. Na era do espaço virtual e do tempo real. Comunicação $e$ Sociedade, 12, 23-38. doi: 10.17231/comsoc.12(2007).1094

Cunha, T. C. (2009). Argumentação e metáfora no discurso político. Comunicação e Sociedade, 16, 19-25. doi: $10.17231 /$ comsoc.16(2009).1027

Duelo de aperto de mão rouba a cena em encontro Trump-Trudeau (2017, $14^{\text {th }}$ February). Veja. Retrieved from http:// veja.abril.com.br/blog/headlines/duelo-de-aperto-de-maos-rouba-a-cena-em-encontro-trump-trudeau/

Eco, U. (1985). La guerre du faux. Paris: Editions Grasset \& Fasquelle.

Fabris, A. (2004). A captação do movimento: do instantâneo ao fotodinamismo. ARS, 7, 51-77. doi: 10.1590/ $\mathrm{S} 1678-53202004000400005$

Flusser, V. (1998). Ensaio sobre a fotografia: para uma filosofia da técnica. Lisbon: Relógio d'água.

Freund, G. (1983). La fotografía como documento social. Barcelona: Grafos S.A.

Giddens, A. (2008). Sociologia. Lisbon: Fundação Calouste Gulbenkian.

Gonçalves, A. (2002). O delírio da disformidade. O corpo no imaginário grotesco. Comunicação e Sociedade, 4, 117-130. doi: 10.17231/comsoc.4(2002).1286

Gradim, A. (2007). O que pedem as imagens? Comunicação e Sociedade, 12, 189-200. doi: 10.17231/ comsoc.12(2007).1104

Horta, N. B. (2015). O meme como linguagem da internet: uma perspectiva semiótica. Master Dissertation, UNB, Brasília, Brazil. Retrieved from http://repositorio.unb.br/bitstream/10482/18420/1/2015_ NataliaBotelhoHorta.pdf

Hunt, E. (2016, $17^{\text {th }}$ December). What is fake News? How to spot it end what you can do to stop it. The Gardian. Retrieved from https://www.theguardian.com/media/2016/dec/18/what-is-fake-news-pizzagate

Jacobs, H. C. (2014). Lo grotesco como programa de la ilustrácion em el Capricho 4 de Francisco de Goya. Acta/Artis. Estudis d'Arts Moderns, 2, 69-95.

Joly, M. (1994). Introdução à análise da imagem. Lisbon: Edições 70.

Machado, A. (1984). A ilusão especular. São Paulo: Brasiliense/Funarte.

Máquina fotográfica Leica vendida por valor recorde (2010, $5^{\text {th }}$ December). TVI 24. Retrieved from http:// www.tvi24.iol.pt/economiamedia-e-tecnologia/fotografia-maquina-fotografica-leica-leilao-dinheiroagencia-financeira/1215461-2974.html

Martins, M. L. (2011). Crise no Castelo da Cultura. Coimbra: Grácio Editor.

Mauad, A. M. (2008). O Jânio que ficou na retina. Revista de História. Rio de Janeiro: Biblioteca Nacional. Retrieved from http://www.revistadehistoria.com.br/secao/perspectiva/o-janio-que-ficou-na-retina

Pinto, S. \& Martins, M. L. (2017). Lógicas de vinculação na arte. Comunicação e Sociedade, 31, 253-269. doi: $10.17231 /$ comsoc.31 (2017).2616

Propp, V. (1992). Comicidade e riso. São Paulo: Ática.

Schilder, P. F. (1999). The image and appearance of the human body. Studies in the constructive energies of the psyche. London: Routledge. 
Sontag, S. (2004). Sobre fotografia. São Paulo: Companhia das Letras.

Sousa, J. P. (1998). Uma história crítica do fotojornalismo ocidental. Porto: Universidade Fernando Pessoa.

Sousa, J. P. (2001). Elementos de Jornalismo Impresso. Porto: Universidade Fernando Pessoa.

Sousa, J. P. (2002). Fotojornalismo: uma introdução à história, às técnicas, à linguagem. Porto: Universidade do Porto.

The Guardian (2017, $14^{\text {th }}$ February). Donald Trump's strange handshake style and how Justin Trudeau beat it [video]. The Guardian. Retrieved from https://www.theguardian.com/us-news/video/2017/feb/14/ donald-trumps-strange-handshake-style-and-how-justin-trudeau-beat-it-video-explainer

\section{WEBGRAPHY}

All world wars. Crimean War Photographs by Rober Fenton, March-June 1855. Retrieved from http://www. allworldwars.com/Crimean-War-Photographs-by-Roger-Fenton-1855.html.

Esso. Ano de 1962, Prémio Principal. Retrieved from http://www.premioexxonmobil.com.br/site/premio_ principal/index.aspx?year $=1962$

Magnum Photos. Overview. Retrieved from https://www.magnumphotos.com/about\%2omagnum/overview/.

Magnum Photos. Henri-Cartier Bresson. Retrieved from https://www.magnumphotos.com/photographer/ henri-cartier-bresson/.

Nikon, History. Chronicles. Vol. 4. Nikon F2. Retrieved from http://imaging.nikon.com/history/chronicle/ rhnco4f-e/index.htm.

Phantom. Phantom Camera Products. Ultrahigh-Speed Cameras. Retrieved from https://www. phantomhighspeed.com/Products/Ultrahigh-Speed-Cameras.

SanDisc. History of the SanDisk Brand. Retrieved from https://www.sandisk.com/about/company/history.

\section{Biographical Notes}

Alene Lins is a PhD student in the Doctoral Programme in Communication Sciences of the University of Minho and Communication and Society Research Centre (CECS) researcher. Professor at the Federal University of Recôncavo da Bahia, teaches photography and image theory. She worked as a journalist, was photografer and reporter of television in Brazil. Her research interests focus on changes in the image after the digital process.

E-mail: aleneufrb@gmail.com

Rua Dr. José Vilaça, 75, 6²A, São Lázaro - 4705-094 Braga, Portugal

Madalena Oliveira is an Associate Professor at the Institute of Social Sciences and member of the Communication and Society Research Centre of the University of Minho. $\mathrm{PhD}$ in Communication Sciences, teaches Semiotics, Communication and Languages, Journalism and Sound and Specialist Journalism. Her research focuses on the radio 
medium and sound as language. She is vice-president of the Portuguese Association of Communication Sciences (Sopcom), coordinator of Sopcom's Radio and Sound Working Group and chair of Ecrea's Radio Research Section.

E-mail: madalena.oliveira@ics.uminho.pt

Institute of Social Sciences - University of Minho - Campus de Gualtar - 4710-057 Braga, Portugal

Luís António Santos is an Associate Professor at the Institute of Social Sciences and member of the Communication and Society Research Centre of the University of Minho. PhD in Communication Sciences and Deputy Director of the Communication and Society Research Centre. He worked as a journalist for more than a decade, including as London correspondent for the Diário de Notícias, during his time with the BBC. His research interests focus on changes in the field of journalism, radio and sound production. He is a commentator and regularly produces chronicles for Rádio Renascença.

E-mail: Isantos@ics.uminho.pt

Institute of Social Sciences - University of Minho - Campus de Gualtar - 4710-057 Braga, Portugal

* Submitted: 16-08-2017

* Accepted: 15-11-2017 